\title{
A new Stygonitocrella Petkovski (Copepoda: Harpacticoida) from a cave in Northern Mexico with comments on the taxonomy of the genus
}

\author{
E. Suárez-Morales ${ }^{1,2, *}$ \& T.M. Iliffe ${ }^{3}$ \\ ${ }^{1}$ El Colegio de la Frontera Sur (ECOSUR), Unidad Chetumal, A.P. 424 Chetumal, Quintana Roo 77000, Mexico \\ ${ }^{2}$ National Museum of Natural History, Smithsonian Institution, Washington, DC, USA \\ ${ }^{3}$ Department of Marine Biology, University of Texas A\&M, Galveston, TX 77553-1675, USA \\ (*Author for correspondence: Tel.: +983-8350440 ext 4304, Fax: +983-8350440 ext 4102, \\ E-mail:esuarez@ecosur-qroo.mx.)
}

Received 30 December 2002; in revised form 5 January 2005; accepted 5 January 2005

Key words: cave fauna, freshwater copepods, troglobitic, invertebrate taxonomy

\begin{abstract}
The cave-dwelling harpacticoid copepod fauna of Mexico is still yet to be known. There are only a few records related to karstic caves, but most refer to epigean forms. The analysis of samples collected in a cave system in Northern Mexico yielded two female specimens of an unknown harpacticoid copepod species which is described herein. It was assigned to the genus Stygonitocrella Petkovski, 1976 mainly because of the presence of a single endopodal segment on legs 1-4; the new species, $S$. mexicana $\mathrm{n}$. sp. differs from its congeners by a combination of characters related to the segmentation and armature of the swimming legs $1-4$, the fifth leg of the female, and the strcture of the antennae. Based on the current limits of Stygonitocrella, two new subgenera are proposed to recognize different morphological patterns based on the presence or absence of an inner baseoendopodal lobe in the female fifth leg, a character not evaluated before. This lobe is absent in the new species and in other five species now contained in the subgenus Eustygonitocrella. A lobe is present in the new subgenus Fiersiella, also with six species. This is the second record of Stygonitocrella in North America, after S. (Fiersiella) sequoyahi Reid, Hunt \& Stanley, 2003; it is the only North American cave-dwelling species of the genus. It is suggested that the influence of marine transgressions in Northern Mexico was related to the origin of the new species as part of a group of troglobitic forms originated from marine interstitial ancestors that colonized the freshwater caves. A key for the identification of all the known species of Stygonitocrella is also provided.
\end{abstract}

\section{Introduction}

The hypogean copepod fauna of Mexico has been surveyed recently in works developed mainly in the southeast part of the country (Fiers et al., 1996; Suárez-Morales et al., 1996). However, the northern part of Mexico is relatively unknown even for its epigean copepod fauna (Suárez-Morales \& Reid, 1998). Many large cave systems with their associated hypogean water bodies and invertebrate fauna remain undiscovered in this area; copepods have been studied only marginally (Reddell \& Mitchell, 1971). The few data available on the troglobitic copepod fauna of this part of Mexico (see Osorio-Tafall, 1942, 1943; Elías-Gutiérrez \& Suárez-Morales, 1998) suggest that a very diverse and interesting group of cave taxa is yet to be discovered. In fact, the only true troglobitic species of the calanoid family Diaptomidae known in the Americas, Microdiaptomus cokeri OsorioTafall (1942) was described from specimens collected in a complex system of caves of the state of San Luis Potosí, central-northern Mexico, that is part of the Sierra Madre Oriental (Osorio-Tafall, 1942; Elías-Gutiérrez \& Suárez-Morales, 1998). In the same cave system there are two undetermined 
records of harpacticoid copepods, one Canthocamptus sp., and a species of Nitokra (Osorio-Tafall, 1943). Overall, the Mexican freshwater harpacticoid fauna remains largely unknown (Suárez-Morales \& Reid, 1998).

The harpacticoid copepod family Ameiridae includes several poorly known or even undiagnosed genera; one of these is Stygonitocrella, erected by Petkovski (1976) to contain mainly troglobitic or phreatic forms, but it has a wide morphological range. Recently Reid et al. (2003) published a revised definition of the genus. In this work, we present a complete description of a new species of Stygonitocrella that was collected in a spring related to a cave system located in the state of Tamaulipas, northeastern Mexico. Based on two distinct morphological patterns shown by the species currently included within Stygonitocrella, we propose the erection of two new subgenera.

\section{Study area}

The surveyed freshwater habitat is a spring located on the south bank of Rio Guayalejo, Jaumave, in the state of Tamaulipas, Northern Mexico (Fig. 1), which passes through a large canyon crossing the Sierra Madre Oriental. This is a very interesting area which is part of a large geological system that includes sectors of the Mexican states of Coahuila, San Luis Potosí, and Tamaulipas, all related to the Sierra Madre Oriental, in one of the geologically oldest zones of Mexico (Padilla-ySánchez \& Aceves-Quesada, 1990). This zone was inundated by the sea that filled the mid-Cretaceous Mexican Geosyncline (Maldonado-Koerdell, 1964). The sampled pool is located about $50 \mathrm{~m}$ in from the riverbank and consists of a shallow pond about $5 \mathrm{~m}$ in diameter, under a rock ledge. The underwater cave has a maximum depth of $15 \mathrm{~m}$ and trends away from the river for about $100 \mathrm{~m}$ before ascending to a small air-filled chamber with possible dry cave passages leading off. Copepods were collected by divers with a plankton net from the water column and sand bottom in $0-13 \mathrm{~m}$ depths. Other cave-dwelling crustaceans such as the cirolanid isopod Speocirolana disparicornis Botosaneanu \& Iliffe (2000) and unidentified amphipods were also collected from this cave system (Botosaneanu \& Iliffe, 2000).

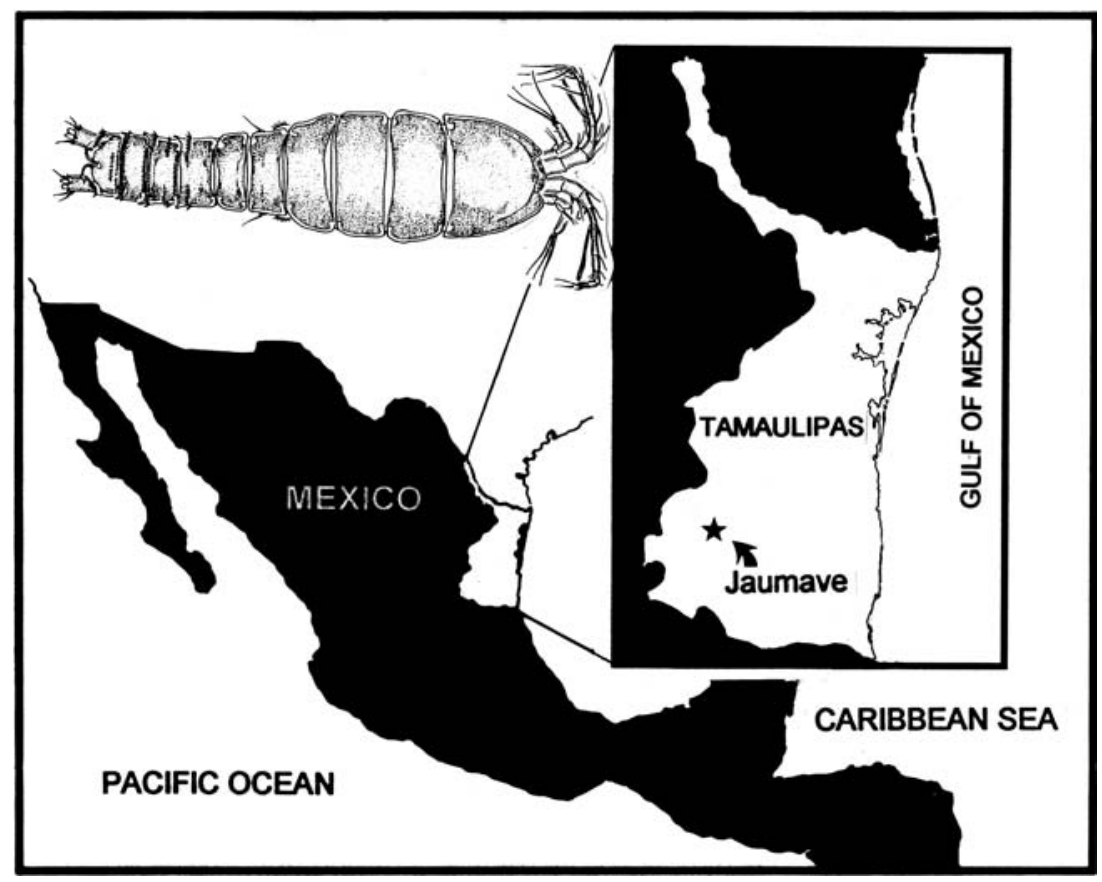

Figure 1. Location of the surveyed area showing Jaumave, Tamaulipas, Mexico, the zone of the type locality (Rio Guayalejo) to Stygonitocrella (Eustygonitocrella) mexicana n. sp. 


\section{Results}

Order Harpacticoida Sars, 1903

Family Ameiridae Monard, 1927

Genus Stygonitocrella Petkovski, 1976 (partim) sensu Reid et al. (2003)

Subgenus Eustygonitocrella n. subgen.

\section{Diagnosis}

With characters of Ameiridae sensu Lang (1948, 1965) and Stygonitocrella as ammended by Reid et al. (2003). Furcal rami subquadrate, sometimes very short. Antennal exopod one-segmented, with 2-4 terminal setae. Exopodites of legs 1-4 three-segmented; endopodites of legs 2 and 3 with the same number of segments $(2,2$ or 1,1$)$ or a combination $(2,1)$. Endopod of leg 4 always one-segmented. Fifth leg of female with inner lobe of baseoendopod always absent. Exopod of female fifth leg with 2-4 setal elements.

\section{Etymology}

The subgenus was named using the Greek prefix "eu" meaning "the original", to denote the inclusion, in this group, of the type species of the genus Stygonitocrella (S. montana), designated by Reid et al. (2003).

\section{Material examined}

Holotype. Adult female, Guayalejo spring, Jaumave, Tamaulipas, northern Mexico. March 15, 1998, coll. Thomas M. Iliffe. Water column $(0-13 \mathrm{~m})$ and sand bottom. Ethanol-preserved, undissected, in vial. Specimen deposited in the Zooplankton collection of El Colegio de la Frontera Sur, Chetumal, Mexico.ECO-CHZ-02759. Paratype. Adult female, ethanol-preserved, dissected, slide on glycerine sealed with Entellan, Guayalejo spring, Jaumave, Tamaulipas, northern Mexico. March 15, 1998, coll. Thomas M. Iliffe. Water column (0-13 m) and sand bottom, deposited in the same collection (ECO-CHZ-02760).

\section{Type locality}

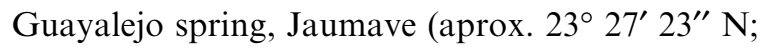
$\left.99^{\circ} 21^{\prime} 15^{\prime \prime} \mathrm{W}\right)$, state of Tamaulipas, Mexico; station number (T.M. Iliffe collections): 98-001. Sample collected 15 March, 1998. The locality is within the limits of the Biosphere Reserve "El Cielo", the largest protected area of northeast Mexico.

\section{Description}

Female (holotype). body (Figs. 2A,B) almost cylindrical, cephalic region relatively wide, body widest at second and third pedigerous somites, tapering posteriorly. Total body length of two individuals: $540 \mu \mathrm{m}$ (holotype) and $520 \mu \mathrm{m}$ (paratype). Cephalotorax with slightly convex, rounded lateral margins, widest in medial portion. Last thoracic and abdominal segments with straight lateral margins; posterior width almost identical in each urosomite. Genital somites fused with distinct medio-dorsal transversal suture band comparable with posterior margins of the other somites; anal somite with parallel lateral margins; anal area moderately deep; furcal rami relatively short, subquadrate, tapering slightly towards posterior edge and about as long as wide. Each furcal ramus with distal spinules on both margins, each of these groups with 3-4 spines, one near inner margin, another near outer margin. Remaining posterior margin with row of minute spinules along insertion of furcal setae. Dorsal seta relatively short, about as long as inner margin of ramus; one outer lateral seta implanted on distal margin, seta near distal third of inner margin and one on distal edge. Inner apical seta longest, measuring $340 \mu \mathrm{m}$; outer apical seta about half the length of inner one $(175 \mu \mathrm{m})$ and much thinner at distal end.

Rostrum (Fig. 2C). articulating with cephalothorax, strongly bent forward in both specimens, wide at base. Lateral margins smooth, tapering distally, no rostral sensilla were observed in specimens examined; rostral tip truncated, not prominent, bent forward; tip grossly bifid, with terminal set of over 10 spinules arranged in one cluster.

Integumental structures. head and cephalothorax area with few scattered pits and sensillae; genital somite with row of spinules near distal margin; abdominal somites furnished with regular pattern of spinules along posterior margin and on middle section of somites. Postgenital somite with two ventral rows of spinules of variable size, one 


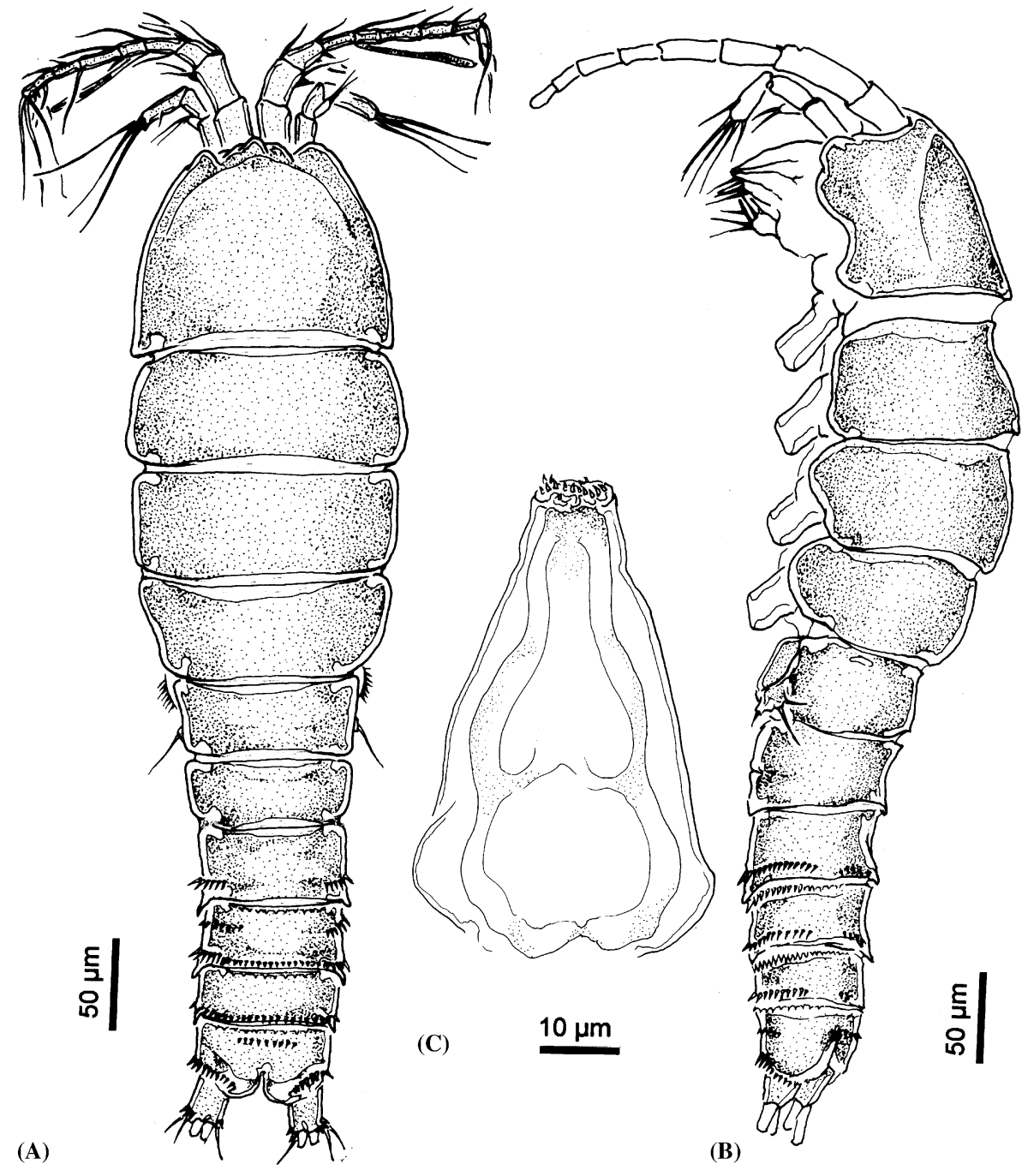

Figure 2A-C. Stygonitocrella (Eustygonitocrella) mexicana $\mathrm{n}$. sp. holotype adult female from Tamaulipas, northern Mexico. (A) habitus, dorsal view; (B) habitus, lateral view; (C) rostrum, ventral view.

incomplete row near anterior margin, formed mainly by short, strong spinules, another complete near posterior margin. Preanal somite with the same ventral pattern of spinules with variable sizes. Anal somite with row of spinules near anterior margin and two rows at the insertion area of both furcal rami (Fig. 4F). Dorsal margins of abdominal somites incised forming lip-shaped processes. Dorsal surface of postgenital somites with rows of spinules and crenulated posterior margins (Fig. 4G). Anal somite with spines showing same arrangement as in ventral surface (Fig. 4E). Intergument of furcal rami smooth except for two groups of spines at insertion of furcal setae and minute spinules along distal margin, near implantation of principal setae.

Antennule (Fig. 3A). eight-segmented, relatively long, measuring $188 \mu \mathrm{m}$ (paratype specimen) and representing a relative length of $28 \%$ of total body length. First antennular segment with curved comb of minute spinules along anterior surface reaching about $1 / 3$ of the segment, and single slender, short seta near starting point of comb. Second segment largest, representing 23\% of the antennule; with one long and six shorter, subequal setae, five inserted on distal half of 


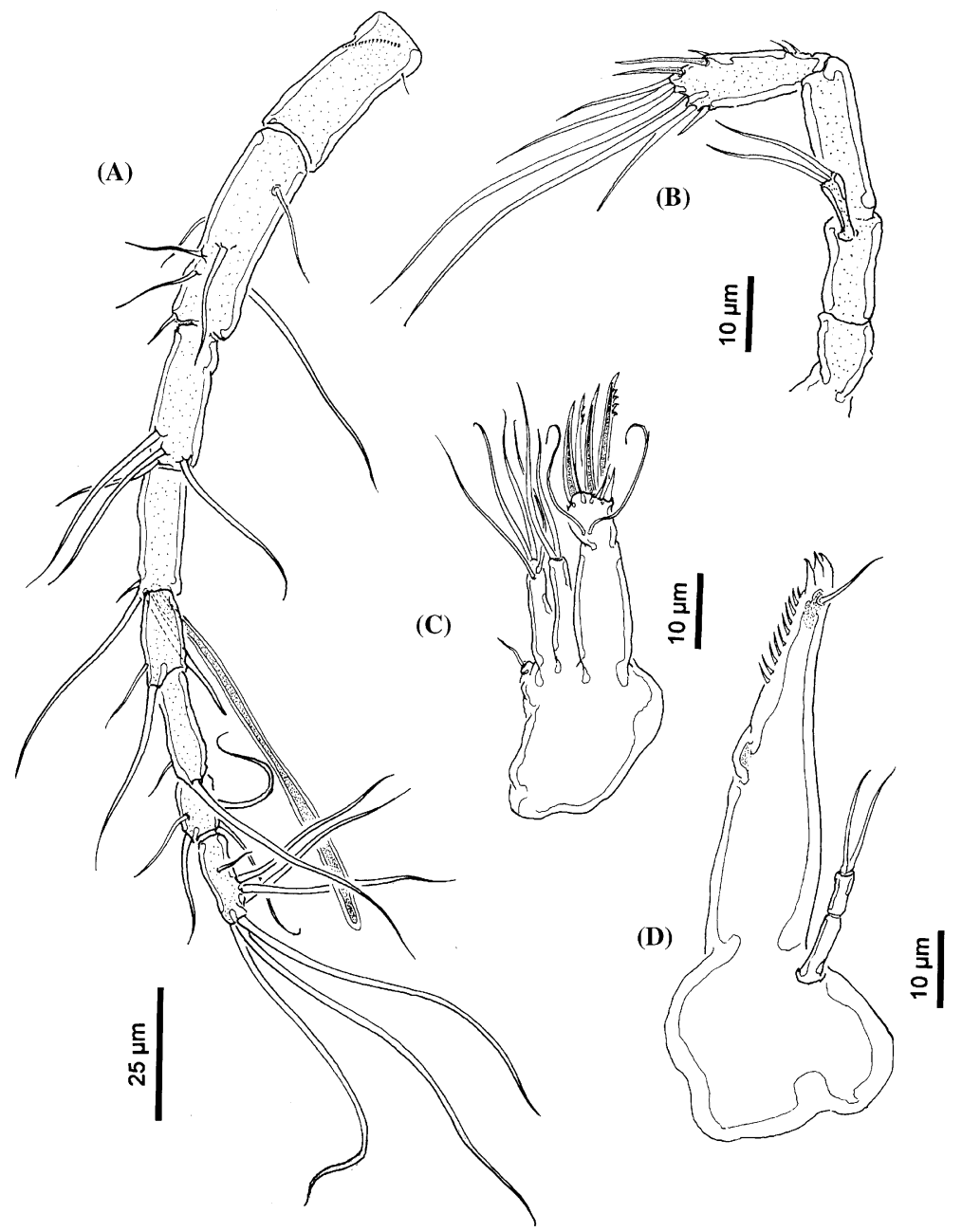

Figure 3A-D. Stygonitocrella (Eustygonitocrella) mexicana n. sp. paratype adult female from Tamaulipas, northern Mexico. A. antennule; B. antenna; C. maxilla; D. mandible.

segment, one on proximal $1 / 3$. Third segment with four subequal setae reaching distal end of succeeding segment, all inserted distally. Fourth segment with long, slender aesthetasc reaching slightly beyond distal antennular segment, plus one long, one medium and one small setae, all inserted distally. Fifth segment with one long and one short distal setae; sixth segment slightly longer than fifth, with same armament. Seventh segment with four setae, one long inserted near proximal margin, plus three relatively short setae subequal in length and breadth inserted on distal half of segment. Last segment with one medial short seta, plus group of three subapical setae and three long apical setae.
Antenna (Fig. 3B). coxa and basis separated, both unarmed; exopodite reduced, represented by a single segment, somewhat elongated, bearing two smooth setae equal in length and breadth; first endopodal unarmed, about as long as second; second endopodal segment with two subdistal spines, two setae, two long and one short apical setae plus one short subdistal seta.

Mandible (Fig. 3D). gnathobase strongly chitinized, wide-based, elongated distally with row of teeth along distal $1 / 3$ of internal margin; gnathal blade narrow, with distal set of three short, slightly curved teeth, outer seta inserted near base of distal teeth. Endopod represented by two slender segments reaching proximal $1 / 3$ of elongated 

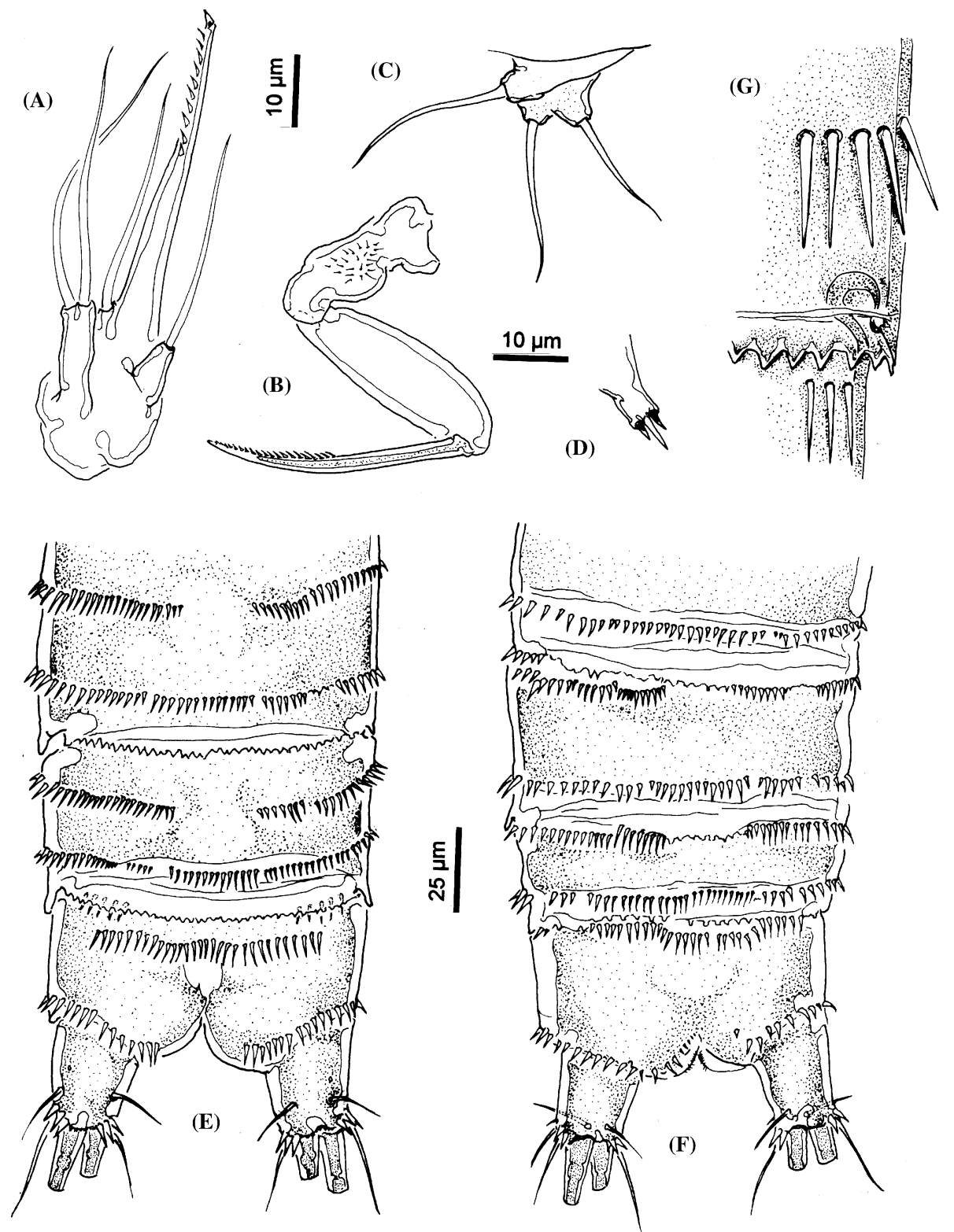

Figure 4A-G. Stygonitocrella (Eustygonitocrella) mexicana n. sp. paratype adult female from Tamaulipas, northern Mexico. (A) maxillule; (B) maxilliped; (C) fifth leg; (D) sixth leg; (E) postgenital somites and furcal rami, dorsal view; (F) postgenital somites and furcal rami, ventral view; $(\mathrm{G})$ detail of crenulated posterior margin of urosomite.

gnathobase; terminal endopodal segment armed with two long terminal setae subequal in length and breadth. Exopod absent.

Maxillule (Fig. 3C). praecoxa with unornamented surface. Arthrite reduced, with naked surface, armed with single short seta. Coxal endite with two terminal plus two subterminal subequal setae. Basal endite with two subequal terminal setae. Endopod two-segmented, first segment long, unarmed, second segment with four strong terminal spiniform setae with uniserial distal row of spinules plus two short setae and two additional setae at base of second segment.

Maxilla (Fig. 4A). syncoxa with one endite bearing two long terminal setae subequal in length and breadth. Allobasis elongated, with distal half 
armed with row of 10 spinules along inner margin; allobasis with one basal seta. Endopod one-segmented, with single long seta.

Maxilliped (Fig. 4B). reduced, basis with group of minute spinules on anterior surface. First endopodal segment unarmed, about 1.5 times the length of basis; endopodal claw strong, straight, slightly curved at tip, 1.3 times longer than bearing segment and armed with uniserial row of internal spinules along distal half.

Armature of swimming legs as (spines in Roman numerals, setae in Arabic) (Figs. 5A-D):

$\begin{array}{llll} & \text { Basis } & \text { Endopodite } & \text { Exopodite } \\ \text { leg } 1 & 1-1 & 0-0 ; 0-0 ; 0-3,0 & \text { I-0;I-0; II,3,0 } \\ \text { leg } 2 & 1-0 & 0-2,0 & \text { I-0;I-1;I,3,0 } \\ \text { leg 3 } & 1-0 & 0-2,1 & \text { I-0;I-1;I,3,0 } \\ \text { leg } 4 & 1-0 & 0-2,1 & \text { I-0; I-I; I,3,0 }\end{array}$

Leg 1 (Fig. 5A). coxa short, subquadrate, with row of 4-5 spinules on outer distal edge plus row of spinules near distal margin; basis subrectangular, with curved inner margin, outer margin straight, inner margin with short plumose seta on distal corner, outer margin with same type of seta, and
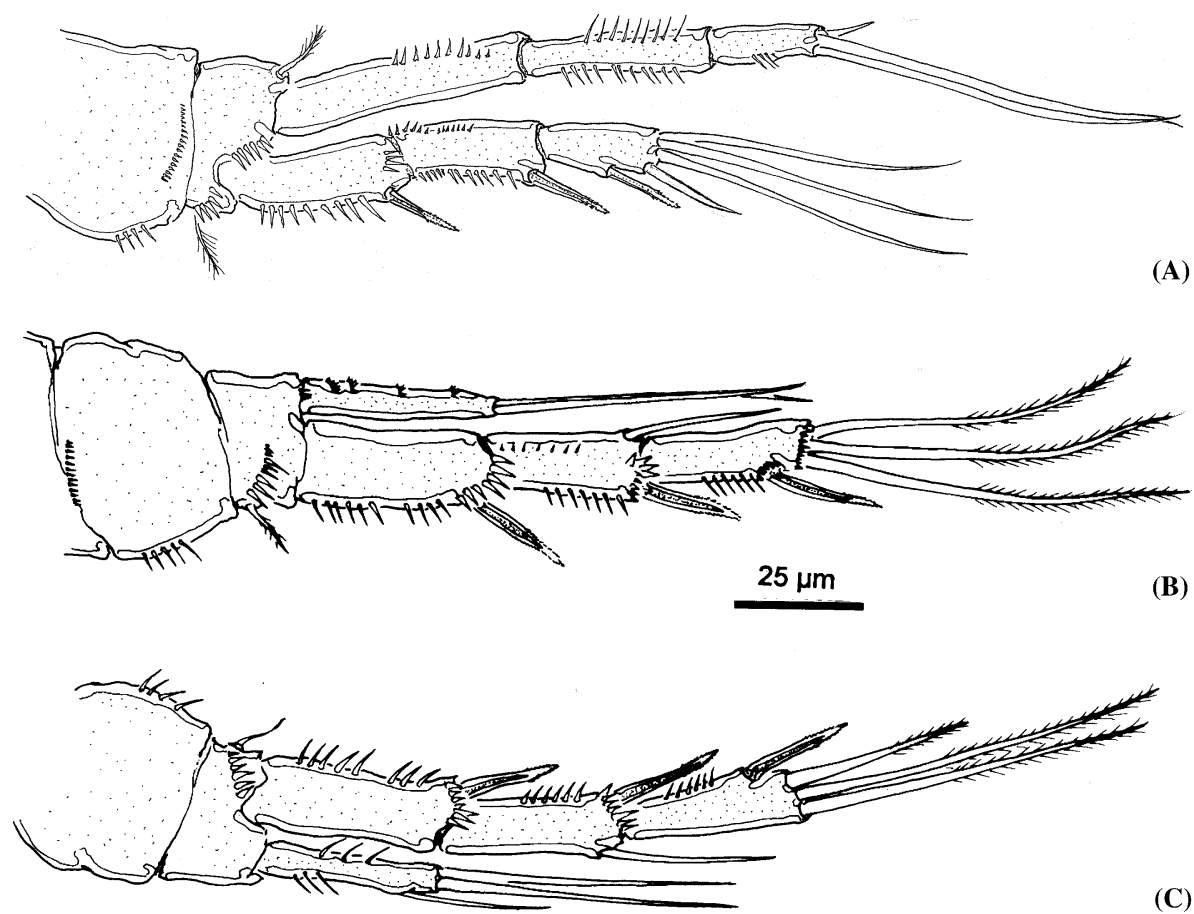

(C)

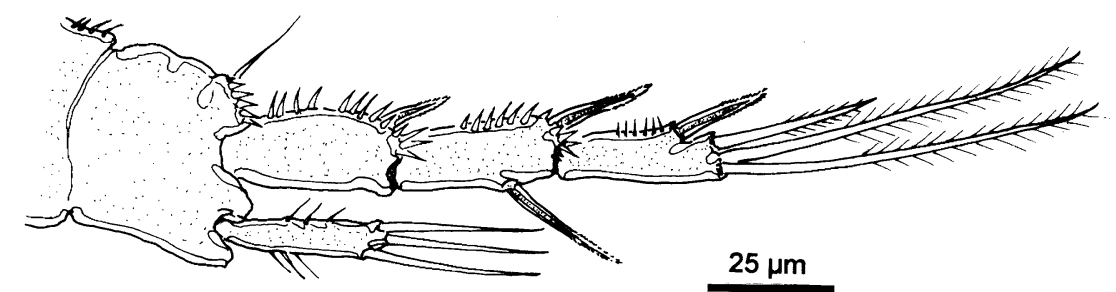

(D)

Figure 5A-D. Stygonitocrella (Eustygonitocrella) mexicana $\mathrm{n}$. sp. holotype adult female from Tamaulipas, northern Mexico. (A) first swimming leg, anterior view; (B) second swimming leg, anterior view; (C) third swimming leg, anterior view; (D) fourth swimming leg, anterior view. 
with row of 3-4 strong spinules; additional row of 5-6 spinules near insertion of exopodal ramus. Exopod three-segmented, first segment with row of long spinules along outer margin and short row of spines near distal margin; second segment with row of spinules along outer margin, row of smaller spinules on inner margin, third segment with no particular cuticular ornamentation. Endopodite longer than exopodite, three-segmented, first segment longest, its distal margin reaching length of distal margin of second exopodal segment, first segment with row of spinules along distal half of inner margin; second segment with two rows of spinules, one along each margin, third segment with short row of spinules on middle section of outer margin.

Leg 2 (Fig. 5B): coxa short, subquadrate, with row of 4-5 spinules on outer distal edge plus row of small spinules near proximal margin. Basis with single short naked seta and row of mixed strong and small spinules decreasing in size from outer margin and reaching near middle of segment anterior surface. Exopod three-segmented, longer than endopod, with rows of spinules along outer margins of each segment and on distal margins on first and second segments. Second segment showing row of small spinules near inner margin, third segment with rows of small spinules along distal margin and at base of subterminal spiniform seta. Endopodite one-segmented, segment as long as first exopodal segment, with four rows of spinules along inner margin.

Leg 3 (Fig. 5C) coxa short, subquadrate, with row of 4-5 spines on outer distal edge. Basis with single short naked seta and row of mixed strong and small spinules increasing in size from outer margin and reaching near insertion of exopod. Exopod three-segmented, longer than endopod, with rows of spinules along outer margins of each segment and on distal margins on first and second segments. Endopod one-segmented, segment as long as first exopod, with inner and outer rows of 3 setules each.

Leg 4 (Fig. 5D): coxa short, subquadrate, with row of 4 spines on outer distal edge. Basis with single short naked outer seta longest of all legs. Row of strong spinules near base of outer basipodal seta. Exopod three-segmented, longer than endopod, with rows of spinules along outer margins of each segment and on distal margins on first and second segments. Endopod one-segmented, as long as first exopodal segment, with four rows of spinules along inner margin.

Leg 5 (Fig. 4C): reduced, baseoendepodite with single outer basal lateral seta, relatively long; exopodite with two subequal setae.

Leg 6 (Fig. 4D): reduced, represented by short subrectangular plate armed with three short distal spiniform setae, middle one about twice as long as outer and inner ones.

\section{Etymology}

The new species is named to make reference to Mexico, the country in which this cave-dwelling harpacticoid copepod was collected.

\section{Remarks}

The new species can be distinguished from the other species assigned to the genus Stygonitocrella by a unique combination of characters: (1) inner lobe of baseoendopod absent; (2) three setal elements on endopod of third swimming legs; (3) the presence of a single endopodal segment on legs 2-4. The latter feature is also present in S. guadalfensis, in Neonitocrella insularis Lee \& Huys, 2002, and S. orghidani; the other species have a different segmentation pattern in these legs (see Table 1). The new species differs from $S$. guadalfensis by the presence in the former of 2 setae on the female fifth leg exopod vs. a 4 setae condition found in S. guadalfensis (see Fig. 4C; Rouch, 1985, fig. $1 \mathrm{~g}$ ); also, the new species has more than one seta $(2,3,3)$ on each endopodal segment of legs 24 , whereas in S. guadalfensis these segments are armed with one seta. There are two distal setae on the antennal exopod in the new species vs. three setae in $S$. guadalfensis. The new species and the monotypic genus Neonitocrella Lee \& Huys, 2002, which contains $N$. insularis (Miura, 1962) share some important characters such as two setae on the exopod of the female fifth leg, and the general setal pattern on swimming legs 2-4; however, $N$. insularis has a unique feature among the species of this genus, that is, the extreme reduction of the endopod of the fourth swimming leg, which is represented by a single, unarmed bud (see Miura, 1962, fig. 18). Furthermore, the new species lacks a spine on the inner margin of the third exopod of the fourth leg; an inner spine is present in 
Table 1. Species of Stygonitocrella sensu Reid et al. (2003) with a comparison of several morphologic characters

\begin{tabular}{llllllll}
\hline Species & ENP2-3 & ENP4 & IBE(N) & SeBE & SAE(N) & SeL3 & GR \\
\hline S. guadalfensis Rouch, 1985 & 1,1 & 1 & Absent & 4 & $1(3)$ & 1 & I \\
S. mexicana n.sp. & 1,1 & 1 & Absent & 2 & $1(3)$ & 3 & I \\
S. montana (Noodt, 1965) & 2,2 & 1 & Absent & 3 & $1(3)$ & 1 & I \\
S. orghidani (Petkovski, 1973) & 1,1 & 1 & Absent & 0 & $1(2)$ & 1 & I \\
S. pseudotianshanica (SSterrba, 1973) & 2,1 & 1 & Absent & 2 & $1(3)$ & 2 & I \\
S. tianshanica (Borutzky, 1972) & 2,1 & 1 & Absent & 3 & $2(4)$ & 2 & I \\
S. colchica (Borutzky \& Mikhailova, 1970) & 2,2 & 1 & Present(2) & 4 & $1(3)$ & 2 & II \\
S. dubia (Chappuis, 1937) & 1,1 & 1 & Present(4) & 3 & $1(3)$ & 1 & II \\
S. karamani (Petkovsky, 1959) & 2,2 & 1 & Present(2) & 4 & $1(3)$ & 2 & II \\
S. ljovshkini (Borutzky, 1967) & 1,1 & 1 & Present(3) & 4 & $1(3)$ & 2 & II \\
S. petkovskii Pesce (1985) & 2,2 & 1 & Present(2) & 4 & $1(3)$ & 2 & II \\
S. sequoyahi Reid, Hunt \& Stanley (2003) & 2,2 & 1 & Present (2) & 4 & $1(3)$ & 2 & II \\
\hline
\end{tabular}

ENP2-3, number of segments on endopod of legs 2 and 3, respectively; ENP4, number of segments on endopod of leg 4; IBE, inner lobe of baseoendopod of fifth legs; $(N)$, number of setae; SeBE, number of setae on the exopod of fifth legs; SAE, number of setae on antennal exopod. GR, Subgenus group to which the species is assigned (see text): I, subgenus Eustygonitocrella; II, subgenus Fiersiella.

$N$. insularis. Additionally, the antennal exopod in S. (E.) mexicanus bears three seta vs two setae in $N$. insularis. These and other differences leaded Lee \& Huys (2002) to exclude this species from Stygonitocrella. The new species differs from its geographically closest congener S. orghidani from Cuba by having a relatively well developed exopod of the female fifth leg; this structure is very reduced in S. orghidani, represented by an outer lobe armed with a single seta (see Petkovski, 1973, fig. 10). Also, although they have some characters in common, such as the number of setae on the antennal exopod, they differ also in the number of elements on the endopod of the third swimming leg. In fact, the three setae condition present in the new species diverges from the other species of the genus; the other species show one or two elements in the corresponding endopod (see Table 1). (4) The new species lacks an inner seta or spine on the third exopodal segment of the fourth swimming leg. One or two elements are always present in the other known species of the genus (see Lee \& Huys, 2002, Table 1).

Genus Stygonitocrella sensu Reid et al. (2003) Fiersiella subgen. nov.

\section{Diagnosis}

General body characters as in Stygonitocrella as diagnosed by Reid et al. (2002). Furcal rami subquadrate or elongated, cyclindrical. Antennal exopod one-segmented, always with 3 terminal setae. Exopodites of legs 1-4 three-segmented; endopodites of legs 2 and 3 always with the same number of segments $(2,2$ or 1,1$)$. Endopod of leg 4 always one-segmented. Female with fifth leg inner lobe of baseoendopod always present, armed with 2-4 setal elements. Exopod of female fifth leg sometimes with 3 , but usually 4 setal elements.

\section{Etymology}

This new subgenus is named after Dr Frank Fiers (Royal Institute of Natural Sciences, Brussels, Belgium) for his outstanding contribution to the knowledge of the Mexican marine and freshwater Harpacticoida.

\section{Remarks}

The species of Stygonitocrella assigned herein to be included under this new subgenus are: S. (Fiersiella) dubia (Chappuis, 1937) from Northern Spain, $S(F$.$) ljovshkini (Borutzky, 1967) from Russia, S$. (F.) karamani (Petkovski, 1959) from Yugoslavia, S. (F.) colchica (Borutzky \& Mikhailova, 1970) from Azerbajian, S. (F.) petkovskii (Pesce, 1985) from Greece, and $S$. (F.) sequoyahi Reid, Hunt \& Stanley, 2002, from the United States, shown as 
group II in Table 1. Stygonitocrella (Fiersiella) dubia is designated herein as the representative species of this subgenus for three main reasons: (1) it was the first member of the subgenus to be described; (2) it has a relatively plesiomorphic character of 6 elements on the third exopodal segment of the fourth legs vs. a 4 or 5 elements condition in the other species; (3) it shows another important plesiomorphy, the strongest development of the inner lobe of the baseoendopod, with the highest number of setal elements. We excluded S. djirgalanica Borutzky,1978 from this analysis because we agree with Reid et al. (2003) that this species, lacking fifth legs in males and females, and with no type material available (Lee \& Huys, 2003), has an uncertain taxonomical status.

\section{Discussion}

In the key for the identification of the ameirids published by Lang (1965), the Mexican specimens examined herein key down to the subfamily Ameirinae and then, quite directly, to the genus Nitocrella Chappuis (partim) because of the onesegmented endopods on legs 2-4. In a revision of the genus (sensu restricto), Petkovski (1976) reconsidered the previous effort by Lang (1965) and splitted this genus into three taxa: (1) Nitocrella sensu stricto, featuring a 2-segmented endopod on legs 2-4; (2) Nitocrellopsis, with 2-segmented endopods on leg 4 and 3-segmented endopods on legs 2 and 3, and (3) Stygonitocrella, distinguished by having a one-segmented endopod on legs 4 and one or two segments on legs 2 and 3 . Following the key published by Petkovski (1976), the Mexican specimens were identified as a species of Stygonitocrella. Our morphological considerations and data about all the species of Stygonitocrella sensu Petkovski were obtained from the original descriptions.

It is recognized here that Stygonitocrella as proposed by Reid et al. (2003) represents two separate subgeneric groups, each with distinctive characters as shown in the diagnoses section. The two morphological groups detected from this analysis are shown in Tables 1 and 2, and in the diagnoses of each taxon. As stated by Galassi et al. (1999) and Lee \& Huys (2002), the characters related to segmentation and armature of the legs 1-4 have been used commonly to sort harpacticoid ameirid genera and this tendency could lead to different taxonomical problems. In fact, these characters, along with the troglobitic habitat of all the species included, were the only ones used by Petkovski (1976) to erect Stygonitocrella. The

Table 2. Seta and spine formula of legs 2-4 of species of Stygonitocrella (s.str.) and Fiersiella gen. nov

\begin{tabular}{|c|c|c|c|c|c|c|c|c|c|c|c|c|c|c|c|}
\hline \multirow[t]{3}{*}{ Species } & \multicolumn{5}{|c|}{$\mathrm{P} 2$} & \multicolumn{5}{|c|}{$\mathrm{P} 3$} & \multicolumn{5}{|c|}{ P4 } \\
\hline & \multicolumn{3}{|c|}{ Exp } & \multicolumn{2}{|c|}{ Enp } & \multicolumn{3}{|c|}{ Exp } & \multicolumn{2}{|c|}{ Enp } & \multicolumn{3}{|c|}{ Exp } & \multicolumn{2}{|c|}{ Enp } \\
\hline & 1 & 2 & 3 & 1 & 2 & 1 & 2 & 3 & 1 & 2 & 1 & 2 & 3 & 1 & 2 \\
\hline S. guadalfensis & 1 & 2 & $0,3,1$ & 0 & - & 1 & 2 & $0,3,1$ & 1 & - & 1 & 2 & $2,3,1$ & 1 & - \\
\hline S. insularis & 1 & 2 & $0,2,2$ & 2 & - & 1 & 2 & $0,2,2$ & 2 & - & 1 & 2 & $1,3,1$ & 0 & - \\
\hline S. mexicana & 1 & 2 & $0,3,1$ & 2 & - & 1 & 2 & $0,3,1$ & 3 & - & 1 & 2 & $0,3,1$ & 1 & - \\
\hline S. montana & 1 & 2 & $0,2,2$ & 0 & 1 & 1 & 2 & $0,2,2$ & 0 & 1 & 1 & 2 & $1,3,1$ & 1 & - \\
\hline S. orghidani & 1 & 2 & $1,2,1$ & 1 & - & 1 & 2 & $1,2,1$ & 1 & - & 1 & 2 & $1,2,1$ & 1 & - \\
\hline S. pseudotianshanica & 1 & 2 & $0,2,2$ & 1 & 2 & 1 & 2 & $0,2,2$ & 2 & - & 1 & 2 & $2,2,2$ & 1 & - \\
\hline S. tianshanica & 1 & 2 & $0,2,2$ & 0 & 2 & 1 & 2 & $0,2,2$ & 2 & - & 1 & 2 & $2,2,2$ & 1 & - \\
\hline F. colchica & 1 & 2 & $0,2,2$ & 0 & 1 & 1 & 2 & $0,2,2$ & 0 & 2 & 1 & 2 & $1,2,2$ & 1 & - \\
\hline F. dubia & 1 & 2 & $0,2,2$ & 1 & - & 1 & 2 & $0,2,2$ & 1 & - & 1 & 2 & $2,2,2$ & 1 & - \\
\hline F. karamani & 1 & 2 & $0,2,2$ & 0 & 2 & 1 & 2 & $0,3,1$ & 0 & 2 & 1 & 2 & $0,2,2$ & 1 & - \\
\hline F. ljovshkini & 1 & 2 & $0,3,1$ & 1 & - & 1 & 2 & $0,3,1$ & 2 & - & 1 & 2 & $0,3,1$ & 1 & - \\
\hline F. petkovskii & 1 & 2 & $0,3,1$ & 0 & 1 & 1 & 1 & $0,3,1$ & 0 & 2 & 1 & 2 & $0,3,1$ & 1 & - \\
\hline
\end{tabular}

P2, second leg; P3,third leg; P4, fourth leg. Exp, exopodal ramus; Enp, endopodal ramus. Setal series as: inner, terminal, and outer elements. 
main character we used to split the two subgenera of Stygonitocrella proposed here was not the reduced number of endopodal segments (1 or 2) on legs 2-4. Such a criterion would have made us to split the genera into 5 groups, each with a distinct segmentation pattern on the endopods of legs 2-4 as: (I) $1,1,1$; (II) 2, 1, 1; (III) 2, 2, 1; (IV) 2, 1, 1; (V) 1,1,0 (see Table 1). Instead, we considered that reductions in the number of endopodal segments of the swimming legs or similar reductions in other appendages of the body are probably features shared by other troglobitic forms (Rouch, 1994). It is clear that stygobitic harpacticoids show characters produced by a convergent evolution; this process might obscure their phylogenetic relationships (Galassi, 1997). We agree with Galassi et al. (1999) in considering other characters present within the genus. In this case, after analyzing the differences among the species, we advance the presence or absence of an inner lobe on the baseoendopod as a defining character by which two groups can be sorted independently from the segmentation pattern of the endopods of legs 2 and 3. In his revision and key of the Ameiridae, Lang (1965) used the number of setal elements on the baseoendopod of the female fifth leg to sort some of the ameirid genera. The absence of such a structure which is widely present throughout the family seems to be a relevant character; to our knowledge this kind of reduction is present in only a few other groups of the Harpacticoida (i.e. Paramesochridae: Scottopsyllus) (Lang, 1965), and to the best of our knowledge, it is not found in any other known members of the Ameiridae. Therefore, the erection of these new subgeneric taxa seems to be justified.

This is the second nominal record of the genus Stygonitocrella in North America and the first one in Mexico. The first record is represented by Stygonitocrella (Fiersiella) sequoyahi (Reid, Hunt \& Stanley, 2003) first published as a nomen nudum in Williamson \& Reid (2001) as part of a survey of the North American fauna. Stygonitocrella (Eustygonitocrella) mexicana n. sp. also represents the only strictly troglobitic harpacticoid known from North America. The other American species of this genus are $S$. montana from Argentine, and S. orghidani from Cuba. The troglobitic diaptomid calanoid M. cokeri, known from the same geological area of the new Stygonitocrella, shows interesting affinities with cave-dwelling European forms (see Elías-Gutiérrez \& Suárez-Morales, 1998). The subgenus Eustygonitocrella is distributed in widely separated geographic areas (Japan, Afghanistan, Russia, South America, Cuba, Mexico), but not in central western Europe. The subgenus Fiersiella is distributed only in western, central, and eastern Europe (Yugoslavia, Spain, Azerbajian, Greece, Russia). Boxshall \& Jaume (2000) suggested that the main lineage of subterranean ameirid harpacticoids probably originated in Laurasia and had more than one colonization events; however, the current distribution of Stygonitocrella, with mostly tropical-temperate forms and with only one representative in North America or in Northern Europe seems to represent either a different tendency or a secondary lineage with septentrional ancestors.

The origin of some groups of the troglobitic crustacean fauna in Northern Mexico has been hypothesized by Cole \& Minckley (1966, 1970), suggesting marine ancestors for some of these taxa (mainly cirolanid Isopoda). For harpacticoid copepods, two main general trends have been proposed: (1) freshwater origin, and (2) marine origin (Rouch, 1994). The family Ameiridae is mainly marine; out of the nearly 32 genera known, only nine contain freshwater forms and up to seven (Praeleptomesochra Lang, 1965, Pseudoleptomesochrella Lang, 1965, Parapseudoleptomesochra Lang, 1965; Nitocrellopsis Petkovski, 1976, Nitocrella Chappuis, 1923, Stygonitocrella, and now Fiersiella gen nov.) are exclusivelly cavedwelling taxa. Some genera, such as Nitocra (one of the most diverse of the family) have invaded the freshwater epigean environments and their subterranean forms are supposedly derived from the epigean species. Other taxa have interstitial, non-epigean marine relatives suggesting a secondary colonization of caves (see Rouch, 1986, 1994; Rouch \& Danielopol, 1987). However, as noted by Rouch (1994), in the exclusively freshwater hypogean genera (Nitocrellopsis, Stygonitocrella, Nitocrella, Fiersiella), the two models are potential explanations. Therefore, considering the paleography of the Tamaulipas, Coahuila-San Luis Potosí area in Northern Mexico, it is speculated that a marine ancestor to Stygonitocrella colonized these caves. According to the evolutionary pathways described by Holsinger (2000), 
S. (E.) mexicana n. sp. would be a limnostygobiont with a marine-limnic transition resulting from stranding during marine regressions. In support of this idea, it has been recognized that continental ameirids are probably marine relicts (Galassi, 2001). It should be added that the ancestors of these forms are probably non-epigean. Of course, more information about other elements of the local harpacticoid fauna will be needed in order to sustain or correct this theory. Species of the ameirids Parapseudoleptomesochra and Nitocrella are present in the karstic cave-related fauna of the Yucatan Peninsula (Suárez-Morales et al., 1996), an area with an interesting succession of marine transgressions and regressions.

Some of the characters shown by Stygonitocrella (E.) mexicana $\mathrm{n}$. sp. are probably related to life in the caves, such as: (1) the unusual elongation of its mouthparts (mandibles, maxillulae, maxillae) and legs (endopods of legs 2-4 are noticeably slender); (2) the reduction of the number of endopodal segments of legs 2-4; (3) the relatively long antennules; (4) the smooth, delicate cuticula. It is puzzling, however, the function of the peculiar rostral tip, with those probably sensorial spines much helpful in these environments; the narrow mandibular blade, which reminds a scraping tool, suggests the feeding behavior of this peculiar species. A similar, elongated, highly modified gnathobase has been described in the Rotundiclipeidae Huys, from caves in Tenerife (Huys, 1988).

Key for the identification of the females of Stygonitocrella

1A. Inner lobe of baseoendopod of the female fifth leg absent. subgenus Eustygonitocrella (7)

1B. Inner lobe of baseoendopod of the female fifth leg present subgenus Fiersiella (2)

2A. Inner lobe of baseoendopod of the female fifth leg with 2 setae. Endopod of legs 2 and 3 with 2 segments; second segment of exopod of leg 1 without an inner seta

2B. Inner lobe of baseoendopod of the female fifth leg armed with more than 2 setal elements. Endopods of legs 2 and 3 with 1 segment; second segment of exopod of leg 1 with an inner seta ................................. 6

3A. With no inner seta or spine on third exopod of the fourth swimming leg; four elements on same segment

3B. With one inner seta or spine on third exopod of the fourth swimming leg; four or five elements on same segment ...................... 4

4A. Caudal rami 1.5 times longer than wide, five elements on third exopod of fourth swimming leg S. (F.) colchica

4B. Caudal rami 6 times longer than wide, four elements on third exopod of fourth swimming leg.... $S$. (F.) sequoyahi

5A. With one seta on second endopodal segment of leg 2. Anal somite armed with a set of 5 strong spines on middle of posterior margin plus row of 10-12 dorsal spines near base of caudal rami.... S. (F.) petkovskii

5B. With two setae on second endopodal segment of leg 2. Anal somite armed only with a few small spinules near the base of furcae on dorsal view ........................ (F.) karamani

6A. Endopodal segment of leg 3 armed with one seta. Two inner setae on the exopod of leg 4, this segment with 6 elements .. S. (F.) dubia

6B. Endopodal segment of leg 3 armed with two setae. No inner setae on the exopod of leg 4 , this segment with 4 elements

S. (F.) ljovuschkini

7A. Endopod of leg 2 two-segmented, endopod of leg 3 one-segmented

7B. Endopods of leg 2 and 3 one- or two-segmented

8A. Exopod of fifth legs elongated, over 3 times as long as wide, segment armed with 3 setal elements; first endopodal segment of leg 2 unarmed .......................... (E.) tianshanica

8B. Exopod of fifth legs rounded, wide, about 1.5 times as long as wide, segment armed with 2 setal elements; first endopodal segment of leg 2 with an inner spine. S. (E.) pseudotianshanica

9A. Endopods of legs 2 and 3 two-segmented; exopod of the fifth leg with 3 setal elements S. (E.) montana

9B. Endopods of legs 2 and 3 one-segmented; exopod of the fifth leg with 2 or 4 setal elements, or absent. 10 
10A. Exopod of the fifth leg absent, antennal exopod with 2 setae ..........S. (E.) orghidani

10B. Exopod of fifth leg present, antennal exopod with 2 or 3 setae 11

11A. Third exopod of leg 1 with four setal elements. Endopods of legs 2-4 with elliptical shape, widest at mid section, armed with 1 , 1, 1 setae. Antennal exopod with 3 setae. Exopod of fifth legs with 4 setae

S. (E.) guadalfensis

11B. Third exopod of leg 1 with five setal elements. Endopods of legs 2-4 slender, with straight margins, armed with 2, 2, 3 setae. Antennal exopod with 2 setae. Exopod of fifth legs with 2 setae

S. (E.) mexicana n.sp.

\section{Acknowledgements}

We thank Brett Dodson who assisted with the cave diving collection of these specimens during the sampling trip to Northern Mexico. Frank Fiers (Royal Institute of Natural Sciences, Belgium) and Janet W. Reid (Virginia Museum of Natural History) provided valuable comments about the morphology of the new species of Stygonitocrella. This contribution was developed and finished during a sabbatical leave of the first author (ES-M) in the National Museum of Natural History, Smithsonian Institution (NMNH-SI), Washington, DC, under the sponsorship of Frank Ferrari. A key financial support was received from CONACYT through a sabbatical research grant, from the Fulbright Program for Research (CIES), and from the state government of Quintana Roo, Mexico. Chad Walter (NMNH-SI) processed the assignment of the NMNH catalog number of this species and Rosa Ma. Hernández did the same in the ECOSUR reference collection.

\section{References}

Borutzky, E. W., 1967. Biospeleologia Sovietica XXXII. On the genus Nitocrella Chappuis (Copepoda, Harpacticoida). Byulletin Moskovskogo Obshchestva Ispytatelei Rrirody, Otdel Biolohichesky, New Series 72(3): 32-39. (In Russian).
Borutzky, E. W., 1972. Copepoda Harpacticoida from subterranean water of the shore of Issyk-kul and southern Kisilkum. Trudy Zoologichskogo Instituta Leningrad 51: 98-119.

Borutzky, E. W. \& M. Mikhailova-Neikova, 1970. Harpacticoida (Copepoda) of caves in West Georgia, Azerbaijan and Middle Asia. Zoologicheskij Zhurnal 49(9): 1334-1341.

Botosaneanu, L. \& T. M. Iliffe, 2000, On four new stygobitic cirolanids (Isopoda: Cirolanidae) and several already described species from Mexico and the Bahamas. Bulletin de l' Institut Royal des Sciences Naturelles de Belgique, Biologie 70: 23-56.

Boxshall, G. A. \& D. Jaume, 2000. Making waves: the repeated colonization of freshwater by copepod crustaceans. Advances in Ecological Research 31: 61-79.

Chappuis, P. A., 1937. Subterrane Harpacticoiden aus NordSpanien. Buletinul Societatii de Stiinte din Cluj (Roumania) 8: $556-571$.

Cole, G. A. \& W. L. Minckley, 1966. Speocirolana thermydronis, a new species of cirolanid isopod crustacean from Central Coahuila, Mexico. Tulane Studies in Zoology 13: 17-22.

Cole, G. A. \& W. L. Minckley, 1970. Sphaerolana, a new genus of cirolanid isopod from Northern Mexico, with description of two new species. Southwestern Naturalist 15: 71-81.

Elías-Gutiérrez, M. \& E. Suárez-Morales, 1998. Redescription of Microdiaptomus cokeri (Crustacea: Copepoda: Diaptomidae) from caves in central Mexico, with the description of a new diaptomid subfamily. Proceedings of the Biological Society of Washington 111(1): 199-208.

Fiers, F., J. W. Reid, T. M. Iliffe \& E. Suárez-Morales, 1996. New hypogean cyclopoid copepods (Crustacea) from the Yucatan Peninsula, Mexico. Contributions to Zoology 66: 65-102.

Galassi, D. M., 1997. The genus Pseudectinosoma Kunz, 1935: an update, and description of Pseudectinosoma kunzi sp.n. from Italy. Archiv für Hydrobiology 139: 277-287.

Galassi, D. M., 2001. Groundwater copepods: diversity patterns over ecological and evolutionary scales. Hydrobiologia 453/454: 227-253.

Galassi, D. M., P. De Laurentis \& M.-J. Dole-Olivier, 1999. Nitocrellopsis rouchi sp.n., a new ameirid harpacticoid from phreatic waters in France Copepoda: Harpacticoida: Ameiridae). Hydrobiologia 412: 177-189.

Holsinger, J. R., 2000. Ecological derivation, colonization and speciation. In Wilkens H., D.C. Culver \& W.F. Humphreys (eds), Subterranean Ecosystems. Ecosystems of the World 30. Elsevier, Amsterdam: 399-415.

Huys, R., 1988. Rotundiclipeidae fam. nov. (Copepoda, Harpacticoida) from anchialine caves of Tenerife, Canary Islands. Stygologia 4: 42-63.

Lang, K., 1948. Monographie der Harpacticiden. Lund, Hakan Ohlssońs Bøktryckeri, Stockholm, Nordiska Bøkhandeln. Vols. 1-2, 1682 pp.

Lang, K., 1965. Copepoda Harpacticoida from the California Pacific coast. Kungliga Svenska Vetenskaps Akademiens Handlingar, Fjärde Series 10(2): 1-560.

Maldonado-Koerdell, M., 1964. Geohistory and paleogeography of Middle America. In Handbook of Middle America Indians. University of Texas Press, Austin: 3-32. 
Miura, Y., 1962. Subterranean harpacticoid copepods of the Amami group of the Ryukyu Islands. Annotationes Zoologicae Japonenses 35: 95-105.

Noodt, W., 1965. Crustacea subterranea aus Argentinien. Beiträge sur Neotropischen Fauna 4: 84-129.

Osorio-Tafall, B., 1942. Diaptomus (Microdiaptomus) cokeri, nuevos subgénero y especie de diaptómido de las cuevas de la región de Valles (San Luis Potosí, México).(Copep., Calan.). Ciencia 3: 206-210.

Osorio-Tafall, B., 1943. Observaciones sobre la fauna acuática de las cuevas de la región de Valles, San Luis Potosí (México). Revista de la Sociedad Mexicana de Historia Natural 4: 43-71.

Padilla-y-Sánchez, R. J. \& J. F. Aceves-Quesada, 1990. Geología. Atlas Nacional de México. Instituto de Geografía. Universidad Nacional Autónoma de México, Mapa 1: 4,000 000. México.

Pesce, G. L., 1985. Stygiobiological researches in subterranean waters of Lesbos (Greece) and description of Stygonitocrella petkovskii n.sp. (Crustacea: Copepoda: Ameiridae). Fragmenta Balcanica 12(273): 125-139.

Petkovski, T. K., 1959. Neue und bemerkenswerte Harpacticoide Ruderfußkrebse, (Crust. Cop.) aus den Grundgewässern Jugoslaviens. Acta Musei Macedonici Scientiarium Naturalium 6(5/57): 101-119.

Petkovski, T. K., 1973. Subterrane Süsswasser-Harpacticoida von Kuba (Vorläufige Mitteilung). Résultats des Expéditions Biospéologiques Cubano-Roumaines a Cuba 1: 125-141.

Petkovski, T. K., 1976. Drei neue Nitocrella-Arten von Kuba, zugleigch eine revision das Genus Nitocrella Chappuis (s. restr.) (Crustacea, Copepoda, Ameiridae). Acta Musei Macedonici Scientiarium Naturalium 15(126): 1-26.
Reddell, J. R. \& R. W. Mitchell, 1971. A checklist of the cave fauna of Mexico. I. Sierra del Abra, Tamaulipas and San Luis Potosí. Studies on the cavernicole fauna of Mexico. Association for Mexican Cave Studies Bulletin 4: 137-180.

Reid, J. W., G. W. Hunt, \& E. H. Stanley, 2003. A new species of Stygonitocrella (Crustacea : Copepoda : Ameiridae), the first report of the genus in North America. Proceedings of the Biological Society Washington 116(4): 996-1006.

Rouch, R., 1985. Une nouvelle Stygonitocrella (Copepoda, Harpacticoida) des eaux souterraines d' Andalousie, Espagne. Stygologia 1: 118-127.

Rouch, R., 1986. Copepoda: les Harpactico souterrains des eaux douces continentales. In Botosaneanu, L (ed), Stygofauna Mundi. E.J. Brill/Backhuys, Leiden: 322-355.

Rouch, R., 1994. Encyclopaedia Biospeologica. Vol. I. Societé de Biospéologie. Moulis, France: 105-111.

Rouch, R. \& D. L. Danielopol, 1987. L'origine de la faune aquatique souterraine entre le paradigme du refuge et le modele de la colonisation active. Stygologia 3(4): 345-372.

Suárez-Morales, E., J. W. Reid, T. M. Iliffe \& F. Fiers, 1996. Catálogo de los copépodos (Crustacea) continentales de la Península de Yucatán, México. CONABIO/ ECOSUR. Mexico. 298 pp.

Suárez-Morales, E., \& J.W. Reid, 1998. An updated list of the free-living freshwater copepods (Crustacea) of Mexico. Southwestern Naturalist 43(2): 256-265.

Sterba, O., 1973. Die neuen Harpacticidenarten der Gattung Nitocrella (Crustacea, Copepoda) aus Afghanistan. Zoologischer Anzeiger 190: 333-342.

Williamson, C.E. \& J.W. Reid, 2001. Copepoda. In Thorp J. H. \& A. P. Corvich (eds), Ecology and Classification of North American Freshwater Invertebrates. 2nd edn. Academic Press, New York: 915-954. 